\title{
Vegetable Leafminer, Liriomyza sativae Blanchard (Insecta: Diptera: Agromyzidae) ${ }^{1}$
}

\author{
J. L. Capinera²
}

\section{Distribution}

The vegetable leafminer, Liriomyza sativae Blanchard, is found commonly in the southern United States from Florida to California and Hawaii, and in most of Central and South America. Occasionally it is reported in more northern areas because it is transported with plant material. It cannot survive cold areas except in greenhouses.

\section{Life Cycle and Description}

The developmental thresholds for eggs, larvae, and pupae are estimated at 9 to 12 degrees $C$. The combined development time required by the egg and larval stages is about seven to nine days at warm temperatures ( 25 to 30 degrees $\mathrm{C}$ ). Another seven to nine days is required for pupal development at these temperatures. Both egg-larval and pupal development times lengthen to about 25 days at 15 degrees $\mathrm{C}$. At optimal temperatures (30 degrees $\mathrm{C}$ ), the vegetable leaf miner completes development from the egg to adult stage in about 15 days.
Egg

The white, elliptical eggs measure about 0.23 $\mathrm{mm}$ in length and $0.13 \mathrm{~mm}$ in width. Eggs are inserted into plant tissue just beneath the leaf surface and hatch in about three days. Flies feed on the plant secretions caused by oviposition, and also on natural exudates. Females often make feeding punctures, particularly along the margins or tips of leaves, without depositing eggs. Females can produce 600 to 700 eggs over their life span, although some estimates of egg production suggest that 200 to 300 is more typical. Initially, females may deposit eggs at a rate of 30 to 40 per day, but egg deposition decreases as flies grow older.

\section{Larva}

There are three active instars, and larvae attain a length of about $2.25 \mathrm{~mm}$. Initially the larvae are nearly colorless, becoming greenish and then yellowish as they mature. Black mouthparts are apparent in all instars, and can be used to differentiate the larvae. The average length and range of the mouthparts (cephalopharyngeal skeleton) in the three

1. This document is EENY-255, one of a series of Featured Creatures from the Entomology and Nematology Department, Florida Cooperative Extension Service, Institute of Food and Agricultural Sciences, University of Florida. Published: December 2001. This document is also available on Featured Creatures Website at http://creatures.ifas.ufl.edu. Please visit the EDIS Website at http://edis.ifas.ufl.edu and the Entomology and Nematology Department website at http://entnemdept.ifas.ufl.edu/.

2. J. L. Capinera, chairmain/professor, Department of Entomology and Nematology, Insititute of Food and Agricultural Sciences, University of Florida, Gainesville, FL.

The Institute of Food and Agricultural Sciences (IFAS) is an Equal Employment Opportunity - Affirmative Action Employer authorized to provide research, educational information and other services only to individuals and institutions that function without regard to race, creed, color, religion, age, disability, sex, sexual orientation, marital status, national origin, political opinions or affiliations. For information on obtaining other extension publications, contact your county Cooperative Extension Service office. Florida Cooperative Extension Service / Institute of Food and Agricultural Sciences / University of Florida / Larry R. Arrington, Interim Dean 
larval feeding instars is $0.09(0.6-0.11), 0.15$

(0.12-0.17), and $0.23(0.19-0.25) \mathrm{mm}$, respectively. The mature larva cuts a semicircular slit in the mined leaf just prior to formation of the puparium. Almost invariably, the slit is cut in the upper surface of the leaf. The larva usually emerges from the mine, drops from the leaf, and burrows into the soil to a depth of only a few $\mathrm{cm}$ to form a puparium. A fourth larval instar occurs between puparium formation and pupation, but this is generally ignored by authors (Parrella 1987).

\section{Pupa}

The reddish brown puparium measures about 1.5 $\mathrm{mm}$ in length and $0.75 \mathrm{~mm}$ in width. After about nine days the adult emerges from the puparium, principally in the early morning hours, and both sexes emerge simultaneously. Mating initially occurs the day following adult emergence, but multiple matings by both sexes have been observed, and up to a month post-emergence.

\section{Adult}

The adults are principally yellow and black in color. The shiny black mesonotum of L. sativae is used to distinguish this fly from the closely related American serpentine leafminer, Liriomyza trifolii which has a grayish black mesonotum. Also, the black hind margin of the eyes serves to distinguish this insect from L. trifolii, which has eyes with yellow hind margins. Females are larger and more robust than males, and have an elongated abdomen. The wing length of this species is 1.25 to $1.7 \mathrm{~mm}$, with the males averaging about $1.3 \mathrm{~mm}$ and the females about $1.5 \mathrm{~mm}$. The small size of these flies serves to distinguish them from pea leafminer, Liriomyza huidobrensis (Blanchard), which has a wing length of 1.7 to $2.25 \mathrm{~mm}$. The yellow femora of vegetable leafminer also help to distinguish these species, as the femora of pea leafminer are dark. Flies normally live only about a month. Flies are uncommon during the cool months of the year, but often attain high, damaging levels by mid-summer. In warm climates they may breed continuously, with many overlapping generations per year.

The biology of $L$. sativae is not well documented because until fairly recently it was confused with

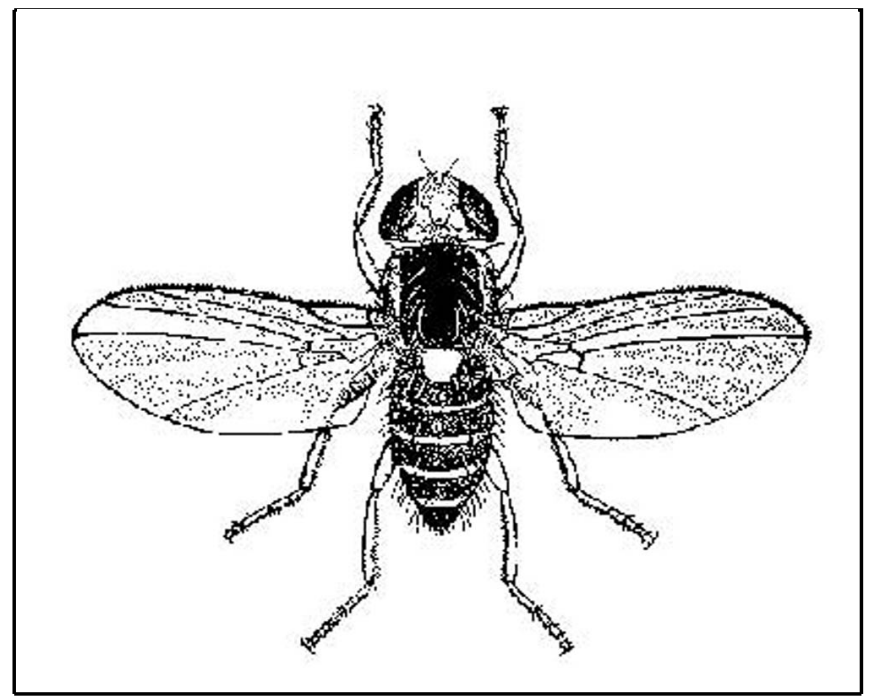

Figure 1. Adult vegetable leafminer. Credits: John L. Capinera, University of Florida

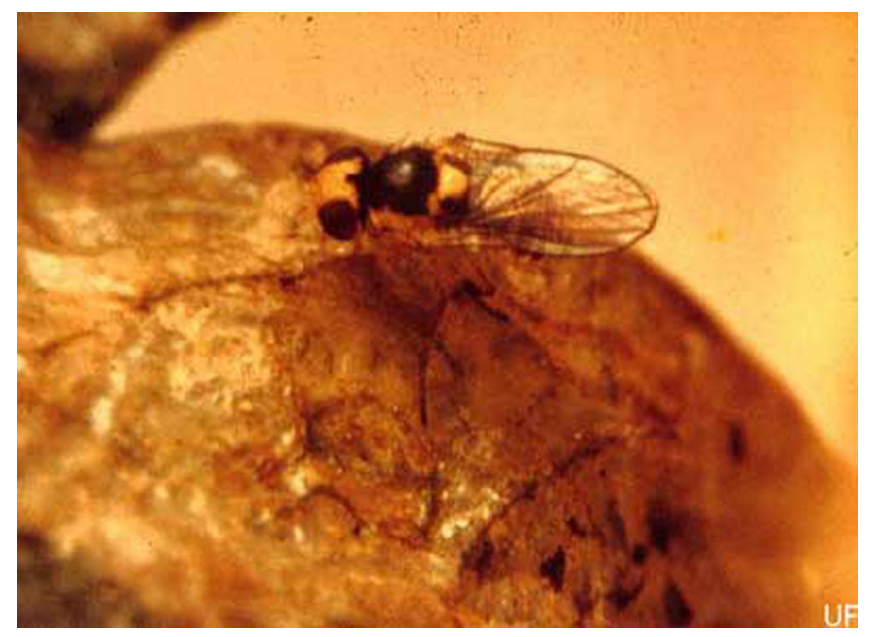

Figure 2. Adult vegetable leafminer Liriomyza sativae Blanchard. Credits: University of Florida

other similar flies, but important elements have been studied by Parkman et al. (1989), Petitt and Wietlisbach (1994), and Palumbo (1995). The work by Oatman and Michelbacher (1958) probably refers to L. sativae. Keys for the identification of agromyzid leafminers can be found in Spencer and Steyskal (1986).

\section{Host Plants}

Vegetable leafminer attacks a large number of plants, but seems to favor those in the plant families Cucurbitaceae, Leguminosae, and Solanaceae. Stegmaier (1966a) reported nearly 40 hosts from 10 plant families in Florida. Among the numerous weeds infested, the nightshade, Solanum americanum; and Spanishneedles, Bidens alba; are especially suitable 
hosts in Florida (Schuster et al. 1991). Vegetable crops known as hosts in Florida include bean, eggplant, pepper, potato, squash, tomato, and watermelon. In California, Oatman (1959) reported a similar host range, but also noted suitability of cucumber, beet, pea, lettuce and many other composites. Celery is also reported to be attacked, but to a lesser extent by this leafminer species than by American leafminer, Liriomyza trifolii (Burgess). In Hawaii, damage to onion foliage is a problem for the marketing of scallions (green onions) (Kawate and Coughlin 1995). Vegetable leafminer was formerly considered to be the most important agromyzid pest in North America (Spencer 1981), but this distinction is now held by L. trifolii

\section{Damage}

Foliage punctures caused by females during the acts of oviposition or feeding may cause a stippled appearance on foliage, but this damage is slight compared to the leaf mining activity of larvae. The irregular mine increases in width from about $0.25 \mathrm{~mm}$ to about $1.5 \mathrm{~mm}$ as the larva matures, and is virtually identical in appearance and impact with the mines of L. trifolii. Larvae are often easily visible within the mine where they remove the mesophyll between the surfaces of the leaf. Their fecal deposits are also evident in the mines. The potential impact of the mining activity is evident from the work of Sharma et al. (1980), who studied the value of treating squash with insecticides in California. These authors reported 30 to $60 \%$ yield increases when effective insecticides were applied, but as is often the case with leafminers, many insecticides were not effective.

\section{Natural Enemies}

Vegetable leafminer is attacked by a number of parasitoids, with the relative importance of species varying geographically and temporally. In Hawaii, Chrysonotomyia punctiventris (Crawford) (Hymenoptera: Eulophidae), Halicoptera circulis (Walker) (Hymenoptera: Pteromalidae), and Ganaspidium hunteri (Crawford) (Hymenoptera: Eucoilidae) were considered important in watermelon (Johnson 1987). In California and Florida, the same genera or species were found attacking vegetable leafminer on tomato or bean, but
Opius dimidiatus (Ashmead) (Hymenoptera: Braconidae) also occurred commonly in Florida (Stegmaier 1966a, Lema and Poe 1979, Johnson et al. 1980a). Levels of parasitism are often reported to be proportional to leafminer density, but parasitoid effectiveness can be disrupted when insecticides are applied. Steinernematid nematodes can infect $L$. trifolii larvae when the nematodes are applied in aqueous suspension and the plants are held under high humidity conditions (Broadbent and Olthof 1995).

\section{Management}

\section{Sampling}

Several methods for population assessment have been studied, and collecting puparia in trays placed beneath plants was recommended by Johnson et al. (1980b) as a labor-saving technique. Zehnder and Trumble (1984) used yellow sticky traps to monitor adults, and reported that $L$. sativae flies were more active at the middle plant height of tomatoes, while $L$. trifolii was more active at low plant height. They also confirmed the value of pupal counts for prediction of adult numbers two weeks later. Yellow sticky traps, however, have the advantage of being able to quickly detect invasion of a field by adults from surrounding areas. Sequential sampling plans were developed by Zehnder and Trumble (1985).

\section{Insecticides}

Foliar application of insecticides is often frequent in susceptible crops Insecticide susceptibility varies greatly both spatially and temporally. Many organophosphate and carbamate insecticides are no longer effective. Insecticides are disruptive to naturally occurring biological control agents, and leafminer outbreaks are sometimes reported to follow chemical insecticide treatment for other insects.

For more insecticidal information see:

Insect Management Guide for Vegetables (http://edis.ifas.ufl.edu/TOPIC_GUIDE_IG_ Vegetables) 


\section{Cultural Practices}

Some crops vary in susceptibility to leaf mining. This has been noted, for example, in cultivars of tomato, cucumber, cantaloupe, and beans (Hanna et al. 1987). However, the differences tend to be moderate, and not adequate for reliable protection. Nitrogen level and reflective mulches are sometimes said to influence leafminer populations, but responses have not been consistent (Chalfant et al. 1977, Hanna et al. 1987). Placement of row covers over cantaloupe has been reported to prevent damage by leafminer (Orozco-Santos et al. 1995). The same study evaluated the benefits of transparent polyethylene mulch, and found no reduction in leafminer populations. Sometimes crops are invaded when adjacent crops are especially suitable, as was reported by Sharma et al. (1980) in California, where cotton was an important source of invaders. Weeds are a source of flies (Parkman et al. 1989), but also a source of parasitoids.

\section{Selected References}

Broadbent, A.B. and T.H.A. Olthof. 1995. Foliar application of Steinernema carpocapsae (Rhabditida: Steinernematidae) to control Liriomyza trifolii (Diptera: Agromyzidae) larvae in chrysanthemums. Environmental Entomology 24:431-435.

Chalfant et al. 1977, Chalfant, R.B., C.A. Jaworski, A.W. Johnson, and D.R. Summer. 1977. Reflective film mulches, millet barriers, and pesticides: effects on watermelon mosaic virus, insects, nematodes, soil-borne fungi, and yield of yellow summer squash. Journal of the American Society of Horticultural Science 102:11-15.

Hanna, H.Y., R.N. Story, and A.J. Adams. 1987. Influence of cultivar, nitrogen, and frequency of insecticide application on vegetable leafminer (Diptera: Agromyzidae) population density and dispersion on snap beans. Journal of Economic Entomology 80:107-110.

Johnson, M.W. 1987. Parasitization of Liriomyza spp. (Diptera: Agromyzidae) infesting commercial watermelon plantings in Hawaii. Journal of Economic Entomology 80:56-61.
Johnson, M.W., E.R. Oatman, and J.A. Wyman. 1980a. Natural control of Liriomyza sativae (Dip.: Agromyzidae) in pole tomatoes in southern California. Entomophaga 25:193-198.

Johnson, M.W., E.R. Oatman, J.A. Wyman, and R.A. van Steenwyk. 1980b. A technique for monitoring Liriomyza sativae in fresh market tomatoes. Journal of Economic Entomology 73:552-555.

Kawate, M.K. and J.A. Coughlin. 1995. Increased green onion yields associated with abamectin treatments for Liriomyza sativae (Diptera: Agromyzidae) and Thrips tabaci (Thysanoptera: Thripidae). Proceedings of the Hawaiian Entomological Society 32:103-112.

Lema, K-M. and S.L. Poe. 1979. Age specific mortality of Liriomyza sativae due to Chrysonotomyia formosa and parasitization by Opius dimidiatus and Chrysonotomyia formosa. Environmental Entomology 8:935-937.

Oatman, E.R. 1959. Host range studies of the melon leaf miner, Liriomyza pictella (Thomson) (Diptera: Agromyzidae). Annals of the Entomological Society of America 52:739-741.

Oatman, E.R. and A.E. Michelbacher. 1958. The melon leafminer, Liriomyza pictella (Thomson) (Diptera: Agromyzidae). Annals of the Entomological Society of America 51:557-566.

Orozco-Santos, M., O. Perez-Zamora, and O. Lopez-Arriaga. 1995. Floating row cover and transparent mulch to reduce insect populations, virus diseases and increase yield in cantaloupe. Florida Entomologist 78:493-501.

Palumbo, J.C. 1995. Developmental rate of Liriomyza sativae (Diptera: Agromyzidae) on lettuce as a function of temperature. Southwestern Entomologist 20:461-465.

Parkman, P., J.A. Dusky, and V.H. Waddill. 1989. Biological studies of Liriomyza sativae (Diptera: Agromyzidae) on castor bean. Environmental Entomology 18:768-772. 
Parrella, M.P. 1987. Biology of Liriomyza. Annual Review of Entomology 32:201-224.

Petitt, F.L. and D.O. Wietlisbach. 1994. Laboratory rearing and life history of Liriomyza sativae (Diptera: Agromyzidae) on lima bean. Environ. Entomol. 23:1416-1421.

Schuster, D.J., J.P. Gilreath, R.A. Wharton, and P.R. Seymour. 1991. Agromyzidae (Diptera) leafminers and their parasitoids in weeds associated with tomato in Florida. Environmental Entomology 20:720-723.

Sharma, R.K., A. Durazo, and K.S. Mayberry. 1980. Leafminer control increases summer squash yields. California Agriculture 34:21-22.

Spencer, K.A. 1981. A revisionary study of the leaf-mining flies (Agromyzidae) of California. Univ. California Special Publication 3273. 489 pp.

Spencer, K.A. and G.C. Steyskal. 1986. Manual of the Agromyzidae (Diptera) of the United States. USDA, ARS Agricultural Handbook 638. 478 pp.

Stegmaier, C.E. 1966a. Host plants and parasites of Liriomyza munda in Florida (Diptera: Agromyzidae). Florida Entomologist 49:81-86.

Zehnder, G.W. and J.T. Trumble. 1984. Spatial and diel activity of Liriomyza species (Diptera: Agromyzidae) in fresh market tomatoes. Environmental Entomologist 13:1411-1416.

Zehnder, G.W. and J.T. Trumble. 1985. Sequential sampling plans with fixed levels of precision for Liriomyza species (Diptera: Agromyzidae) in fresh market tomatoes. Journal of Economic Entomology 78:138-142. 